\title{
Determinants of Board Size in an Emerging Market
}

\section{August 2014}

\section{Byung S. Min}

\begin{abstract}
Drawing largely upon the selective adaptation paradigm, the resource dependence literature and the capture argument, we examine determinants of board size using panel dataset of Korean listed companies that have experienced dramatic changes in their governance system following the 1997 Asian crisis and regulatory reforms. Observing that the firm's compliance with statutory requirements reflects a strategic choice, our results also investigate the idea that the determinants of board size differ between firms actively and passively adapting to regulatory reforms. For actively adaptive firms, board size increases along with firm complexity but it varies inversely with the power of controlling shareholders (CSHs). In contrast, the roles of complexity and CSHs are not significant but seniority-based promotion is an important factor to increase the size for the passive firms. Our results suggest that determinants of board size differ depending on corporate strategies to comply with statutory requirements in an emerging market where family business is dominant and corporate governance system have substantially changed.
\end{abstract}

JEL Classification: L53; M21; G34; G38

Key words: board size, corporate governance, regulatory reform, emerging market (Korea)

Department of International Business and Asian Studies

Griffith Business School

Griffith University, 170 Kessels Rd.

Tel: 61737355248

Fax: 61737355111

Email: b.min@griffith.edu.au

This is an extension of an earlier working paper "Determinants of Board Size and Structure: Does the Agency Theory Explain All?" We thank the editor (Richard Levich) and an anonymous reviewer for valuable comments. We are grateful to Jerry Bowman, Russell Smyth, Woochan Kim, Youngki Lee, Adrian Cheung, Jaehoon Hahn, Bonyeol Koo, Doocheol Moon, Sangmin Lee, Hyung Chul Chung, Hyuong-Goo Kang, Seung-joo Lee, Joon ho Hahn, Dongwon Kim, Baeho Kim, Jae-un Park, Oh Y. Kwon and seminar participants at Yonsei University, Korea University, Hanyang University, Pusan National University and KDI School for their valuable comments. We also thank Karl Keesman for helping with codification to clean the data and Larry Crissman and Anne Platt for editorial assistance. The usual disclaimer applies. 


\section{Determinants of Board Size in an Emerging Market}

\section{Introduction}

Existing studies on board of directors (BODs) have focused primarily on the effect of a director's decision on firm performance and the role of directors (Payne, Benson and Finegold, 2009; Ravasi and Zattoni, 2006). Board size is an important issue because it directly affects board effectiveness (Pearce II and Zahra, 2007; Chaganti, Mahajan and Sharma, 1985; Pfeffer, 1972; Pfeffer, 1973; Gales and Kesner, 1994; Raheja, 2005; Wu, 2000; Lehn, Patro and Zhao, 2003; Lipton and Lorsch, 1992; Eisenberg et al., 1998). Both consulting and reducing contractual conflicts requires increased numbers of board members. However, increasing numbers are often accompanied by more costs. Further to the increased costs of running a larger board system, human being's opportunism motivates board member to be a free-rider and thus coordination becomes difficult (Yermack, 1996). ${ }^{1}$

Existing studies on board size examined mainly the association of size with firm value in the case of US firms (Yermack, 1996; Eisenberg et al., 1998; Coles et al., 2008). In contrast to the case in the United States, research on corporate boards in Asia is scant although the role of the Asian corporations in the world market has significantly increased (Carney, 2008; Schaede, 1994; Peng, Bhagat and Chang, 2010). In particular, we observe that existing studies assume board size is exogenous. In contrast, we propose that board size is endogenous. Board size can differ depending on a firm's compliance with board regulations such as the appointment of outside directors. A firm that actively responds to board regulation may have a different board size compared to a firm that passively responds. The objective of this paper is to investigate the factors that determine the size of BODs in the case of Korea where the appointment of outside directors is a statutory requirement. 
Regulatory reforms following a series of corporate scandals including Enron, Tyco and WorldCom at the beginning of the new millennium in the U.S. and the Asian region following the 1997 Asian crisis have focused on restructuring of board of directors. These corporate scandals led to the enactment of the Sarbanes-Oxley legislation in the summer of 2002 and the NYSE and NASDAQ corporate governance reform proposals in the US, which in turn prompted governance reforms in other countries. The Sarbanes-Oxley legislation reemphasised the importance of the role of outside directors with the aim of strengthening the function of boards (Dalton and Dalton, 2011; Dey, 2010), although this legislation is not always supported by academics (Combs et al., 2007).

The 1997 Asian financial crisis has also highlighted the idea of introducing outside directors into the board system in the Asian region (OECD, 2001; Boubakri, Guedhami and Mishra, 2010; Mitton, 2002; Min and Smyth, 2014; Min and Verhoeven, 2013). These regulatory reforms stipulate that listed firms must appoint external directors, which in turn affects board size. To comply with this statutory requirement, firms face two strategic options: increase the board size in proportion to the number of outside directors or reduce the size of the board. This reduction strategy is particularly relevant when the law stipulates a minimum percentage of outside directors in board members. Consequently, examining the determinants of board size in the nexus of regulatory reform has become an important issue (Dalton and Dalton, 2011).

The Korean case is unique in that government-led reforms have significantly changed the corporate governance system since the onset of the 1997 Asian financial crisis (OECD, 2001; Kim and Kim, 2008; Becht, Bolton and Roell, 2005; Chizema and Kim, 2010; Black and Kim, 2012; Min and Bowman, 2015). ${ }^{2}$ The essence of the governance reform is the introduction of the Anglo-American model which includes the outside director system (Min and Smyth, 2014; Min and Verhoeven, 2013). The appointment of outside directors directly 
affects board size. An interesting question is that whether or not firms comply with the regulation of the appointment of outsiders actively more than legal requirement, or passively and adhere only to the formal legal requirement. Our research explicitly considers this corporate strategic decision while we investigate the determinants of board size.

Most existing studies on Korea focus on the financial performance of chaebols before the 1997 Asian crisis (Bae, Kang and Kim, 2002; Joh, 2003). Researchers have examined the effect of the outside director system on firm performance such as the Tobin's q and share returns (Choi, Park and Yoo, 2007; Black, Jang and Kim, 2006b; Min and Verhoeven, 2013; Min, 2013). Black, Jang and Kim (2006a), using the corporate governance index, reported that regulation is an important determinant of firms' corporate governance choices. While Dalton and Dalton (2011) address the importance of research on corporate board in the nexus of regulatory reform, few studies are available on the determinants of board of directors.

While our study of BODs is in line with the recent shift in focus of research from mergers and acquisitions (M\&As) to internal governance features (Hermalin and Weisbach, 2003), our investigation also considers the unique features of the Korean economy using the most comprehensive panel data set to be employed for such research, covering all non-financial listed firms on the Korea Exchange during the period 1999-2007. Our estimation model specifically considers the seniority-based promotion tradition, which is different from the Western tradition. In addition, our paper employs various robustness checks to address estimation bias including the possible endogeneity problem.

The remainder of this paper proceeds as follows. The following section provides a literature survey of existing theories with a view to constructing our empirical hypotheses. Section three reviews the reforms to Korea’s corporate governance system following the 1997 financial crisis, including a description of the changes in the legal requirements for listed companies. Compliance by the firms is also described. The paper then goes on to explain our 
estimation model and data, followed by estimation results. These estimation results are presented together with robustness checks. Our conclusions and summary are presented in the final section.

\section{Theory and research hypotheses}

Selective adaptation theory (Potter, 2003, 2004; Nakamura, 2014; Fish, 1980) illustrates that organisational adaptations in response to external shocks can differ depending on the organisation's internal characteristics to perceive and support the shocks as well as the magnitude of complementarity to local norms.

Selective adaptation refers to the adoption and implementation of international management models "to fit the demands of domestic markets and institutions" (Zeitlin and Herrigel, 2000). Such an approach does not treat the subject in terms of unconditional acceptance or rejection of a foreign management practice. In that sense, the concept is similar in many ways to that of translation (Czarniawska-Joerges and Sevón, 1996; Buck and Shahrim, 2005).

In the context of corporate governance, any process of corporate reform towards a foreign model is likely to be complex, evolving in response to some external challenges yet influenced by actions of actors and firms within the local governance system (Sanders and Tuschke, 2007; Chizema and Shinozawa, 2012). Moreover, given the diversity of national governance systems (Aguilera and Jackson, 2003), arguably path dependent and with elements that are complementary in nature (Hall and Soskice, 2001), any adoptions will have to be translated to suit local interests and needs (Buck and Shahrim, 2005).

\subsection{Complexity and board size}


Denis, Langley and Pineault (2002) illustrate that leading a complex organisation is a challenging task. Zahra and Pearce (1989) identify the three key roles of the board as monitoring, service and strategy. A board of directors (BOD) is responsible for making the firm's complex strategic decisions such as selecting the CEO (Mace, 1986), business diversifications (Kroll, Walters and Wright, 2005), bankruptcy reorganisations (Johnson, Hoskisson and Hitt, 1993), resolving conflict of interest inherited in all contractual arrangements involving principles and agents (Gibbs, 1993; Eisenhardt, 1989; Fama and Jensen, 1983), and takeover defences (Mallette and Fowler, 1992).

Traditional agency theory assumes a Berle-Means world where ownership and managerial control are separate. Under this separation of control and ownership, the theory implies that a utility maximising manager will pursue private consumption. The implication of this theory, therefore, is that BODs (outside directors) are expected to resolve contractual conflicts (Dalton et al., 2007; Finkelstein and Hambrick, 1996; Johnson et al., 1996; Fama and Jensen, 1983; Bathala and Rao, 1995; Beasley, 1996; Laux, 2008).

Resource dependence theory regards boards as a mechanism for managing resource dependencies (Pfeffer, 1972; Pfeffer and Salancik, 1978). It suggests that directors will contribute to the board by providing managers with helpful advice based on their own experience. Hillman and Dalziel (2003) and Hillman et al. (2000), extended by Haynes and Hillman (2010) and Dalziel et al. (2011), argue that BODs are a primary mechanism for linking a firm with sources of external dependency. The idea of resource dependence theory is consistent with the appointment of outside directors which in turn affects board size. In the context of firm complexity, there is likely to be a strong ex ante expectation of the usefulness of outside directors who are seen not only to reduce uncertainty along policy reforms but to bring legitimacy and resources to the firm, such as information, skills and access to key constituencies (e.g., suppliers, buyers, public policy decision makers, social groups) (Johnson, 
Daily and Ellstrand, 1996). The complexity of the firm means that insiders rely more on external 'human capital' for effective decision makings. In the context of Korea, Min (2011) and Min and Verhoeven (2013) reported that executive board members of other firms took the largest portion (32.9\%) of the appointed outside directors, followed by university professors (21.6\%), ex-government officer (5.2\%) and accountant (4.1\%). The selective adaptation theory described above, combined with the resource dependence theory, indicates that each firm appoints outsiders who can contribute the most to the firm so that the board is unique to the firm and difficult to be imitated by others. ${ }^{3}$

Complex firms require more resources at least for the following three reasons. Firstly, board's strategic decisions should be based on professional analysis of the complex internal business activities. Carter et al., (2010) propose that one of the board's functions is to provide resources such as information and expertise and creation of channels of communication with constituents of importance for the firm. A small business for simple non-tradable assembling tasks may need board members who are familiar with (domestic) business. However, a firm using complex machines requires professional engineering knowledge in addition to the traditional board members. As such, the size of the board will increase.

Secondly, complex firms tend to face more complex business environments than other firms. The complexity of a firm using new-technology machines imported from overseas is greater than a firm relying on hand-made products. A firm using imported machine needs to analyse the business environment of global markets for the machine as well as international financial matters and foreign exchange markets. Sub-contracting instead of adding a board member is not an alternative when importing is a regular part of the business. The theory of transaction costs (Williamson, 1975, 1985) illustrates that internalisation of routine activities is consistent with the firm's goal of cost minimisation. Internalisation prevents contractual conflicts arising from opportunism. According to the resource dependence theory, the board of 
directors is seen as a tool "to manage external dependency, reduce environmental uncertainty and reduce transaction costs associated with environmental interdependency by linking the organisation with its external environment.” (Lynall et al., 2003).

Thirdly, new technology and intangible assets may also create a complex external environment in terms of regulations and consumers' behaviours. The basic proposition of resource dependence theory implies that board members should serve to connect the firm with external factors by designating the resources needed to survive. According to the resource dependence theory, a board provides commitments of support from important organisations or groups in the external environment and creates an increased appearance of legitimacy for the firm in the external environment (Carter et al., 2010). In addition to business, engineering and international business, firms nominate lawyers and ex government officers to the board in order to obtain 'resources' to manage possible NGO activities against the firm’s legitimacy, policy makers and government regulations. Successful environmental linkages could reduce transaction costs associated with environmental interdependency. Therefore, appointing directors that have influence and access to key policy-makers and government is seen as an important strategy for survival because of their knowledge in their professions and communities. Based on the above theories and reasoning, we hypothesise that:

H1: Board size will increase as the complexity of the firm increases.

\subsection{Human resource management and board size}

Seniority-based promotion has long been an important part of Korea's human resource management approach (Bae and Rowley, 2001; Kim and Briscoe, 1997; Chang and Chang, 1994). Seniority-based promotion is closely related to Confucianism, which regards reputation as a material indicator of life (and family) success and emphasises 'harmony' in an organisation. The implication of a seniority-based promotion policy for the BOD is that such a 
policy heavily influences the appointment of board members. Decisions to promote a senior executive to the BOD may be more related to rewarding the executive than to achieving the optimal composition and size of the board. Assuming that a linear relationship with firm age will capture seniority-based promotion, we hypothesise that:

H2: The size of the board will increase as the age of the firm and its members' length of service rise.

2.3 Role of controlling shareholders and board size

Bebchuck and Weisbach (2010) indicate that the CSH may regard a large board as a burden when seeking to implement business plans such as creating a business empire. Bae, Kang and Kim (2002) and Johnson et al. (2000) demonstrated that business amalgamations by firms with CSHs are common, and are largely inefficient. Young, Peng, Ahlstrom, Bruton and Jiang (2008) show that principal-principal conflict between CSH and minority shareholders should be more pronounced in emerging economies where family business are dominant.

The CSH will have conflicts with board members to the extent that CSH-initiated business diversification is inefficient. This is because one of the board's functions is to resolve conflicts of interest between the CSH and minority shareholders (Fama and Jensen, 1983). Important business strategies such as mergers and acquisitions are subject to board approval (Kroll, Walters and Wright, 2005). Effective BODs have overall accountability for the strategy, direction and internal control of a firm and its performance.

CSHs who want to "capture” the board will regard a large board as a burden (Main et al., 1995). We therefore hypothesise that:

H3: Entrenched CSHs will have a negative association with board size. 


\section{Statutory reforms and compliance in Korea}

3.1 Reform of the corporate governance system

Similar to Japanese firms before World War II, Korean firms traditionally had only internal board members and these traditional board members often became rubber stamps (Schaede, 1994). There was often no clear documentation of the roles and duties of board members. Board meetings were held on a monthly basis but often lasted less than an hour.

Following the 1997 financial crisis, the Korean government initiated regulatory reforms that have significantly changed the nation's corporate governance system, including the structure of corporate boards. An amendment of the Listing Act (Art. 88.2) in February 1998 requires the appointment of outside directors for publicly traded firms. BODs of companies listed on the Korean Exchange must be comprised of at least 25 percent outside directors. We call this the 25 percent rule. To ensure the independence of outside directors, the Act clarified the definition of an outside director by excluding current and former employees of the company, the CSH's family and friends, and anyone who has a business relationship with the firm/business group.

\subsection{Compliance and adjustment of board size}

Owing to these regulatory reforms to board structure and the development of a market for outside directors, listed firms began to appoint outside directors in 1999. Table 1a (row 3) indicates that the proportion of listed firms with at least one outside director increased significantly from 34 percent in 1999 to 62.3 percent in 2000 and to 95 percent in 2007. Both introduction of the new regulations described above and the development of a market for outside directors were the main reasons for this sharp increase. The table also shows that the most common number of outside directors per firm was 2. The term of an outside director in Korea is usually 2-3 years with the possibility of renewing for one more term. 
Table 1a: Election of Outside Directors: Corporations Listed on the Korea Exchange (\%)

Table $1 \mathrm{~b}$ reports that the most frequently observed board size during our sample period is four (24.9 percent of observations), followed by six (14.9 percent) ${ }^{4}$

\section{Table 1b: Distribution of board size}

Further to the appointment of outside directors, Graph 1 shows that Korean listed firms reduced the size of the board during our sample period. Average board size in 1999 was around 6.3 but has decreased to below 6 until 2002 and then remained relatively stable from there on. This trend in board size mainly reflects the statutory requirement to appoint outside directors for at least 25 percent of the board members. The data suggest that Korean listed firms have complied with this statutory requirement by both increasing the appointment of outside directors (i.e., the numerator) and reducing the size of the board (i.e., the denominator).

\section{Graph 1: Trends in the Size of the BOD and Outside Directors}

\subsection{Identification of actively and passively adaptive firms}

Table 2 reports the distribution of board structure in Korea, defined as the ratio of outside directors to board members. The first column of the upper panel shows that 23.66 percent of the listed firms did not appoint any outside directors. ${ }^{5}$ The second column of the table show that around 20 percent of the listed firms 'just' complied with the statutory requirement by having exactly 25 percent outside directors. We call this group of firms that appointed outside directors at a level that was no more than the legal requirement the "passively adaptive" firms. There are at least two reasons for this discretionary appointment of outside directors to have fallen short of the 25 percent requirement. To minimise the adverse effects of this regulatory reform the Korean government provided a grace period at the beginning of the introduction of the outside director system. This was because it was understood that increasing the number of 
outside directors on boards would generate increased costs, including directors' fees and administrative support. The search for suitable outside directors also entailed costs, particularly in an economy where the market for outside directors was still underdeveloped.

The 25 percent rule implies that the appointment of outside directors to more than 25 percent of board positions is voluntary. The bottom row of Table 2 indicates that the cumulative interval frequency for the range 0.0-0.25 was 47.23 percent of all listed firms during our sample period. This figure means that around $42(=52.77-10.8)$ percent of listed firms (excluding large firms, which is 10.8 percent) during 1999-2007 appointed more outside directors than were legally required under the 25 percent rule. We call this group of firms the "actively adaptive" firms.

Table 2: Distribution of Board Structure (Ratio of Outside Directors to Board) (Number, \%, 1999-2007)

\section{Research Design}

4.1 Empirical model

We consider the following panel data model to investigate our research hypotheses in the nexus of firm's strategies to select its board structure actively and passively as described in the previous sections.

$Y_{i t, m}=\beta_{k} \sum_{k=0}^{K} \mathbf{X}_{k t}+\theta_{t}+\psi_{j}+\boldsymbol{\varepsilon}_{i t}$

where,

$Y_{i t, m}=$ board size defined as the integer number of board members form firm $i$ at time $t$.

$m=1$ for actively adapted firms and

$m=2$ for passively adapted firms 
and a vector of control variables $\mathbf{X}_{k t}$ including Seniority, Controlling shareholder ownership, the Performance and Financial Distress variables, and other control variables. $\theta_{t}$ captures time effects and $\psi_{j}$ is to control for industry-level (KSIC two-digit) clustering effects. $\boldsymbol{\varepsilon}_{i t}$ is a timevarying residual.

\subsection{Variables}

To investigate the effect of complexity on board size (Hypothesis H1), we rely on four different proxy variables. Two of these are flow variables: R\&D expenses scaled by sales (rnd2sale) and expenditure on machinery scaled by number of employees (machine2N). These are expected to capture technology-related complexity. The other two are stock variables: the natural logarithms of intangible assets (lintangible) and capital (lcapital). These two variables are expected to capture size-related complexity. Hypothesis H1 implies that all of these variables should have positive coefficients. Seniority is proxied by the firm's age since incorporation. This is because seniority-based promotion is expected to increase the size of board. ${ }^{6}$

The effect of firm performance is examined by including a latent variable of Performance. To avoid multicollinearity, we use a latent variable for firm performance (Performance) extracted by Principle Component Analysis using four variables: lag of the firm’s average operating income scaled by sales in the previous two years; lag of Tobin’s Q, calculated by (market value of ordinary shares plus book value of debt) divided by book value of assets; inverse of volatility of share return, calculated by monthly-based standard deviation of share return; and continuously compounded share return. The expected sign is ambiguous. This is due to the information signalling theory (Bhattacharya and Ritter, 1983; Myers and Majluf, 1984) which implies a positive sign while the bargaining power theory (Hermalin and Weisbach, 1998) which suggests a negative sign. In a similar vein, Miyajima (2008) addressed the importance of financial distress (findistress) as a determinant of the board size. For 
findistress, we include a binary variable with a value of unity when a firm had experienced net losses in the previous two year consecutively and zero otherwise. The expected sign of this variable is negative.

debt2equity, calculated by book values of debt scaled by equity, is also included to account for the effect of the firm's capital structure. Foreignshare is included to capture the effect of foreign investors' equity ownership. Its expected sign is positive because foreign investors are expected to prefer more appointment of outside directors, increasing the size of board.

\subsection{Data}

All annual information on non-financial listed firms was obtained from the Korea Listed Companies Association (KLCA) database, which is the most comprehensive data set for corporations in Korea.

The basic data sources for the KLCA database are business (semi-annual) reports, quarterly reports, and consolidated auditing reports, which are prepared and submitted by all listed corporations according to the Commercial Code and stock exchange laws. This database provides a wide range of corporate information, including balance sheets, income statements, stock prices, auditors' opinions and general information about stock exchange-listed and KOSDAQ-listed corporations. Our data set excluded KOSDAQ-listed firms and financial institutions in order to increase the comparability between firms. ${ }^{7}$ We identified outside directors who had their own office in a firm as well as those who did not have an office, although the majority of outside directors are external. Our data set ranged from 1999 when the firms began to appoint outside directors, to 2007, just before the onset of the global financial crisis brought about by the US subprime mortgage crisis. 
Table 3 reports summary statistics on board size and included regressors. It indicates that the average (median) board size is 5.5 (5.0). We winsorised BOD at the top 1 percent point to remove measurement errors caused by false reports, resulting in a maximum BOD size of 14. However, this winsorising had little effect on the board size: average (median) board size dropped by $0.1(0.0)$.

Table 3: Summary Statistics (1999-2007)

\section{Estimation Results}

\subsection{Baseline Estimation for Board Size}

We estimate the baseline determinants of board size using the Poisson estimator. ${ }^{8}$ The estimation results in Table 5 (Columns 5-9 are without industry effect) support the complexity hypothesis (H1) regardless of the measurement of the variable and model specifications.

\section{Table 4: Benchmark Estimation Results for Board Size}

They also show that the appointment of board members in Korea is positively associated with the seniority-based promotion system (H2). ${ }^{9}$ The average estimated coefficient of Seniority across the models is 0.08, suggesting that the partial effect based on mean values, controlling for other included regressors, is $0.012(=0.08 * 5.45 / 34) .{ }^{10}$ The analysis of this estimated coefficient implies that the effect of seniority-based promotion is statistically but not economically significant. We interpret this finding as supporting the existing studies that suggest that the popularity of seniority-based promotion declined following the 1997 financial crisis (Bare and Rowley 2001; Kim and Park 1997; Kim and Briscoe 1997).

The estimated coefficient of the CSH's equity holding is negative across the estimated models, supporting our research hypothesis H3. This finding is consistent with existing studies (Bae, Kang and Kim, 2002). The negative sign suggests that CSHs in an economy dominated by family businesses regard a large board as an impediment to implementing their business 
plans, such as creating a business empire. As expected, foreign shares are positively associated with large board size whereas financial distress is negatively related. Due possibly to the ambiguous implications of competing theories, the performance variables are not significant except for the specification in Column 8.

\subsection{Estimation of Board Size between Chaebol Affiliates and Stand-alone Firms}

To examine any differences between chaebol affiliates and stand-alone firms, we split the sample into two sub-groups. The classification of chaebol is based on large business groups defined by the Korea Fair Trade Commissions in 2002.

The results in Table 5 reveal that the determinants of board size are different between the two sub-groups. Controlling shareholder (CSH) and foreign share are important determinants for chaebol affiliates whereas seniority-based promotion and performance variables are important for stand-alone firms. This finding supports that the role of CSH is still influential for chaebol affiliates to determine the size of the board even when the amended Commercial Law introduced restrictions on CSH's (illegal) power. Foreign investors have generally preferred chaebol affiliates to stand-alone. Average foreign equity for chaebol affiliates is 13.5 percent which is 5 percentage points larger than that of stand-alone firms. The positive effect of foreign share implies that foreign investors prefer the appointment of outside directors, which in turn increases the size of the board for chaebol affiliates. In contrast to chaebol affiliates, the positive effect of the seniority-based promotion implies that the size of the board is relatively more influenced by internal board member than chaebol affiliates. Indeed, the t-test for the difference of the mean value of the ratio of outsider to board member for stand-alone $(0.277)$ and chaebol affiliate $(0.302)$ is -4.02 (p-value $=0.00)$ supporting our estimation results. The negative sign of Performance for stand-alone supports the bargaining power theory rather than the information theory. 
Table 5: Estimation Results of Board Size between Chaebol Affiliates and Stand-alone Firms

\subsection{Determinants of Board Size for Actively and Passively Adaptive Firms}

To investigate differences in board structure between actively and passively adaptive firms based on the 25 percent rule, we first restrict our sample by excluding large firms, defined by an asset size of more than 2 trillion won (2 billion USD). ${ }^{11}$ Then, we consider whether or not a firm appointed more outside directors than were required by the 25 percent rule. Table 6 reports the estimation results for the actively adaptive firms as appointing more outside directors than required under the 25 percent rule and with a maximum asset size of 2 trillion won (2 billion USD) and vice versa for the passively adaptive firms.

Firstly, the four complexity variables for the actively adaptive firms are more consistently and significantly associated with board size (both in terms of magnitude of coefficient and statistical significance) than those for the passively adaptive firms, as we observed in the case of board structure. This finding implies that our hypothesis (H1) is more relevant to understanding the behaviour of the active firms than the passive firms.

Secondly, Seniority is significant only for the passive firms. This variable is significant even when financial distress (findistress) and firm performance (Performance) are controlled for. By contrast, Seniority is no longer significant for the actively adaptive firms. This finding implies that the actively adaptive firms are more flexible in the use of the seniority-based promotion system to appoint (internal) board members than the passively adaptive firms. This is consistent with our expectation that the actively adaptive firms will place less weight on the traditional promotion system. The results also suggest that all listed firms tend to reduce the number of (internal) board members when they experience financial distress (findistress).

Table 6: Determinants of Board Size for the Actively and the Passively Adaptive Firms (The 25 percent rule) 
Controlling shareholders’ voting power $(\mathrm{CSH})$ shows negative signs for all listed firms but is significant only for the actively adaptive firms, implying that hypothesis H3 is more relevant for understanding the active firms' decision-making process on board size. A further investigation (not reported) indicates that $C S H$ has a positive association with the appointment of outside directors. These results suggest that as the CSHs' voting power increases the impact is observed at the expense of internal board members rather than by reducing the number of outside directors on the board. Considering that the appointment of outside directors is a statutory requirement, this decision-making is an equilibrium outcome for CSHs in the actively adaptive firms.

Coefficients of Performance variable show negative signs consistently for all firms, confirming results from existing studies (Hermalin and Weisbach, 2003; Eisenberg et al., 1998). We interpret this finding as evidence of the trade-off relationship between size and coordination in the Korean context. In a similar vein, the coefficient of financial distress (findistress) shows negative signs for all firms regardless of their strategic decisions on complying with the law. The leverage variable (debt2equity) is negative for all firms although the statistical significance is only for the passively adaptive firms. Joh (2003) attributed high leverage as one of the main characteristics of Korean firms before the 1997 crisis. In addition to a malfunctioning corporate board, the lender's moral hazard failed to control CSH's building business empire (i.e., unprofitable diversification) based on borrowing. However, negative signs of the leverage, combined with negative signs of Performance, in our estimation suggest that lender's awareness of efficiency of board seemed to be increased after the 1997 crisis.

\subsection{Robustness Checks}


One may express concern about reverse causality when the size of board affects included covariates. For example, the size of board increased beyond the threshold level (when costs of the free-rider problem is greater than benefits of diversified 'resources') which would lead to poor performance in year t. Then, the poor performance will negatively affect both internal promotion and appointment of outside directors in year $t+1$ and vice versa. To address the reverse causality problem, we examine three-year averaged determinants of board size where we replace the dependent variable using three-year averaged bod_total $\left(Y_{i t, m} \_\right.$3avg $)$as shown in equation (2).

$$
Y_{i t, m-3 a v g}=\beta_{k} \sum_{k=0}^{K} \mathbf{X}_{k t}+\theta_{t}+\psi_{j}+\boldsymbol{\varepsilon}_{i t}
$$

where all other variables remain as defined for equation (1).

The reverse causality can be reduced to the extent that this three-year averaged dependent variable moderates the ups and downs of firm performance. The included covariates are the same as before without averaging. Therefore, we expect this differenced (only) dependent variable will address the problem of reverse causality. The results in Table 7 confirm that the three-year averaged determinants of board structure are qualitatively the same as our initial estimates shown in Table 6.

\section{Table7: Three-year Averaged Determinants of Board Size for Actively and Passively Adaptive Firms (the 25 percent rule)}

Possible estimation bias caused by confounding associated with the size of the firm is addressed by separating out large firms (i.e., the threshold level of two trillion won). However, another concern is the estimation bias due to endogeneity associated with unobserved variables at the firm level. We use the feasible GLS estimator given the industry effects. However, the feasible GLS assumes that the unobserved firm-level effect is uncorrelated with any of the included covariates. To relax this assumption, we use the instrument variable method (Table 8). First, we calculate the cluster-mean (i.e., firm-mean) centred performance variable for the 
instrument of the performance. This firm-mean centred performance only controls for withinfirm confounders such as composition of employee effect. However, the effects of firm-level variables across the economy (i.e., firm-level confounding for other firm-level variables) are not controlled when measuring the performance of the firm. Thus, we also include the firmmean performance variable to control for this firm-level confounder. For example, a particular type of managerial style may appoint more outside directors and this will lead to rivalry behaviours with other firms. In such cases, the estimated coefficients tend to be overestimated. Estimations by MLE indicate that the null hypothesis of equality between the firm-mean centred and mean of the performance variables is not rejected for the board size. Therefore, this finding supports our main result.

Table 8: MLE Estimates of the Determinants of Board Size for Actively vs. Passively Adaptive Firms (the 25 percent rule)

Further, we ran the Negative Binomial Regression to address the possibility of over- dispersion of the $i$-th observation compared to a true Poisson distribution (Table 9). All of these estimations confirm the robustness of our estimations reporting asymmetry between actively and passively adaptive firms.

Table 9: Negative Binomial Estimates of Determinants of Board Size for Actively vs. Passively Adaptive Firms (the 25 percent rule)

\section{Conclusion}

Our study reports that Korean listed firms have adjusted the size of their boards along with the legislation of board reforms following the 1997 Asian crisis. This legislation of board reform particularly focuses on the outside director system. Interestingly, however, the listed firms use different strategies for the amendment of the Listing Act in 1998 requiring all listed firms to comply with the 25 percent rule. Our analysis based on the KLCA database finds that a large number, 42 percent of all firms (excluding large firms) in our study, are actively adaptive firms 
that appointed outside directors to more than 25 percent of board positions. Our results also show that the average board size has declined. This indicates the importance of voluntary action in determining board size, particularly for the actively adaptive firms.

We find that the determinants of board size differ between the actively and passively adaptive firms. Seniority-based promotion is important for the passive firms even when we control for financial distress and firm performance. By contrast, the actively adaptive firms seem to be more flexible in their approach to using the seniority-based promotion system to appoint (internal) board members. Complexity is significant with a positive sign as the information signalling theory and the resource dependence literature indicate. The negative sign of the CSH is significant. Considering that the appointment of outside directors is a statutory requirement, this finding explains the equilibrium outcome for CSHs. Our estimation results passed various robustness checks.

\section{References}

Aguilera R, Jackson G., 'The cross-national diversity of corporate governance: Dimensions and determinants.' Academy of Management Review, 28 (2003), pp. 447465.

Akerlof, G.A., 'The market for 'lemons': Quality uncertainty and the market mechanism,' Quarterly Journal of Economics 84 (1970), pp. 488-500.

Bhattacharya, S., 'Imperfect information, dividend policy and 'the bird in the hand' Fallacy.' Bell Journal of Economics 10 (1979), pp. 259-70.

Bae, J.S. and Rowley, K. 'The impact of globalisation on HRM: The case of South Korea.' Journal of World Business, 36 (2001), pp. 402-428.

Bae, K-H, Kang J-K., and Kim, J-M., 'Tunneling or value added? Evidence from mergers by Korean business groups.’ Journal of Finance (2002), pp. 2695-2740.

Bathala, C., and Rao, R.P., 'The determinants of board composition: an agency theory perspective.' Managerial and Decision Economics 16, (1995), pp. 59-69.

Beasley, M., 'An empirical analysis between the board of director composition and financial statement fraud.' Accounting Review 71 (1996), pp. 443-466.

Bebchuk, L.A. and Weisbach, M.S., 'The state of corporate governance research,' Review of Financial Studies 23 (2010), pp. 939-961.

Becht, M, Bolton, P. and Roell, A., 'Corporate governance and control' (2005), ssrn.com/abstract_id=343461.

Bhattacharya S. and Ritter JR. 'Innovation and communication: Signalling with partial disclosure,' Review of Economic Studies 50 (1983), pp. 331-346.

Black, B.S., Jang, H., and Kim W., 'Predicting firms' corporate governance choices: Evidence from Korea.' Journal of Corporate Finance 12 (2006(a)), pp. 660-691. 
Black, B. S., Jang, H., and Kim, W., 'Does corporate governance predict firms' market values? Evidence from Korea.' Journal of Law, Economics and Organisation 22 (2006(b)), pp, 366-413.

Black BS, and Kim W, 'The effect of board structure on firm value: a multiple identification strategies approach using Korean data,' Journal of Financial Economics, 104 (2012), pp. 203-226.

Bourbakri, N., Guedhami, O., and Mishra, D., 'Family control and the implied cost of equity: Evidence before and after the Asian financial crisis.' Journal of International Business Studies 41 (2010), pp. 451-474.

Buck T, Shahrim A., 'The translation of corporate governance changes across national cultures: The case of Germany.' Journal of International Business Studies 36 (2005), pp. 42-61.

Carter, D.A., D'Souza, F., Simkins, B.J., and Simpson, W.G.. 'The gender and ethnic diversity of US boards and board committees and firm financial performance.' Corporate Governance: An International Review 18 (2010), p396-414.

Carney M. 'The many features of Asian business groups.' Asia Pacific Journal of Management 25 (2008), pp. 595-613.

Chaganti, R.S., Mahajan, V. and Sharma, S., 'Corporate board size, composition and corporate failure in retailing industry.' Journal of Management Studies 22 (1985), pp. 400-417.

Chizema A. and Kim, J. 'Outside directors on Korean boards: Governance and institutions,' Journal of Management Studies 47 (2010), pp. 109-129.

Chizema, A. \& Shinozawa, Y., 'The company with committees: Change or continuity in Japanese corporate governance.' Journal of Management Studies, 49 ( 2012), pp. 77101.

Chang, C. S., and Chang, N. J., The Korean management system: Cultural, political, economic foundations. (1994), Westport, CT: Quorum Books.

Choi, J.J., Park, SW, and Yoo, S.S., 'The value of outside directors: Evidence from corporate governance reform in Korea.' Journal of Financial and Quantitative Analysis 42 (2007), pp. 941-962.

Choi, K., and Lee, K., Employment adjustment in Korean firms: Survey of 1998. (1998), Seoul: Korea Labor Institute.

Coles, J. L., Daniel, N. D. and Naveen, L. 'Boards: Does one size fit all?' Journal of Financial Economics, 87, (2008), pp. 329-356.

Czarniawska-Joerges B, Sevón G., Translating Organizational Change. (1996), New York: Walter de Gruyter.

Combs, JG. Ketchen Jr. D., Perryman, AA, and Donahue, M. S. 'The Moderating effect of CEO power on the board composition - firm performance relationship.' Journal of Management Studies 44 (2007), pp.1299-1323.

Dalton DR. and Dalton CM. 'Integration of micro and macro studies in governance research: CEO duality, board composition and financial performance.' Journal of Management 37 (2011), pp. 404-411.

Dalziel, T., Gentry, RJ, and Bowerman, M., 'An Integrated Agency-Resource Dependence View of the Influence of Directors' Human and Relational Capital on Firms' R\&D Spending.’ Journal of Management Studies 48 (2011), pp. 1217-1241.

Davis G.F. 'Agent without principles? The spread of the poison pills through the intercorporate network.' Administrative Science Quarterly 36 (1991), pp. 583-613.

Denis J-L, Langley A. and Pineault M. 'Becoming a leader in a complex organisation.' Journal of Management Studies 37 (2002), pp.1063-1100. 
Dey, A., 'The chilling effect of Sarbane-Oxley: A discussion of Sarbane-Oxley and corporate risk-taking.' Journal of Accounting and Economics 49 (2010), pp. 53-57.

Eisenberg, T., Sundgren, S. and Wells, M., 'Larger board size and decreasing firm value in small firms.' Journal of Financial Economics 48 (1998), pp. 35-54.

Eisenhardt K.M. 'Agency theory: An assessment and review.' Academy of Management Review 14 (1989), pp. 57-74.

Fama, E.F., and Jensen, M.C., 'Separation of ownership and control.' Journal of Law and Economics 26 (1983), pp. 301-325.

Finkelstein, S., and Hambrick, D.C., Strategic leadership: Top executives and their effects on organisations (West’s Strategic Management Series). (1996), West: Minneapolis/St. Paul, M.N.

Fish, S. Is There a Text in This Class: The authority of Interpretive communities, (1980), Cambridge, Mass.: Harvard University Press.

Gales, L. and Kesner, I. 'An analysis of board of director size and composition in bankrupt organisations.' Journal of Business Research 30 (1994), pp. 271-82.

Gibbs. PA. 'Determinants of corporate reconstructing: the relative importance of corporate governance, takeover threat, and free cash flow.' Strategic management Journal, 14 (1993), pp. 51-68.

Guest, P.M. 'The determinants of board size and composition: Evidence from the UK.' Journal of Corporate Finance 14 (2008), pp. 51-72.

Hall PA, Soskice D. (eds). Varieties of Capitalism: The Institutional Foundations of Comparative Advantage. (2001), Oxford University Press: New York.

Haynes K.T. and Hillman A. 'The effect of board capital and CEO power on strategic change.' Strategic Management Journal 31 (2010), pp. 1145-1163.

Hermalin, B.E. and Weisbach, M.S., 'Boards of directors as an endogenously determined institution: A survey of the economic literature.' Federal Reserve Bank of New York Economic Policy Review 9 (2003), pp. 7-22.

Hermalin, B.E. and Weisbach, M.S., 'Endogenously chosen boards of directors and their monitoring of the CEO.' American Economic Review 88 (1998), pp. 96-118.

Hillman, A.J., Cannella Jr. A. and Paetzold, R.L., 'The Resource Dependence Role of Corporate Directors: Strategic adaptation of board composition in response to environmental change.' Journal of Management Studies 37 (2000), pp. 235-55.

Hillman, A.C., and Dalziel, T., 'Boards of directors and firm performance: Integrating agency and resource dependence perspectives.' Academy of Management Review 28 (2003), pp. 383-396.

Joh, S.W., 'Corporate governance and firm profitability: Evidence from Korea before the economic crisis.’ Journal of Financial Economics 68 (2003), pp. 287-322.

Johnson, J. Daily, C. and Ellstrand, A. 'Boards of directors: a review and research agenda.’ Journal of Management 22 (1996), pp. 409-348.

Johnson, S., La Porta, R., Lopez-de-Silanes, F., and Shleifer, A. Tunneling. American Economic Review 90 (2000), pp. 22-27.

Kim, S., and Briscoe, D.R., 'Globalization and a new human resource policy in Korea: Transformation to a performance-based HRM.' Employee Relations 19 (1997), pp. 298- 308.

Kim, E. and Kim, W., 'Changes in Korean corporate governance: A response to crisis.' Journal of Applied Corporate Finance 20 (2008), pp. 47-58.

Kim, D., and Park, S., 'Changing patterns of pay systems in Japan and Korea: From seniority to performance.' International Journal of Employment Studies 5 (1997), pp. 117-134. 
Kroll M., Walters, B.A. Wright, P., 'Board vigilance, director experience and corporate outcome,' Strategic Management Journal, 29 (2005), pp.363-382.

Laux, V., 'Board independence and CEO turnover.' Journal of Accounting Research (2008), pp.137-171.

Lehn, K., Patro, S., and Zhao, M., 'Determinants of the size and structure of corporate boards: 1935-2000.' (2003), Working Paper, University of Pittsburgh, November.

Lipton, M., and Lorsch, J.W., 'A Modest Proposal for Improved Corporate Governance’’ The Business Lawyer 48 (1992), pp.59-78.

Lynall, M.D., Golden, B.R., and Hillman, A.J. (2003), ' Board composition from adolescence to maturity: a multitheoretic view.' Academy of Management Review (2003), 28, p416-431.

Mace, M. Directors: Myth and Reality, (1986), Boston: Harvard Business School Press.

Mack, Y.T., and Li, Y., 'Determinants of corporate ownership and board structure: evidence from Singapore.' Journal of Corporate Finance 7 (2001). pp.235-256.

Main, B.G.M., O’Reilly III, C.A., and Wade, J., 'The CEO, the board of directors and executive compensation: Economic and Psychological perspective.' Industrial and Corporate Change 4 (1995), pp.293-332.

Mallette P. and Fowler, K.L. 'Effects of board composition and stock ownership on the adoption of poison pills.' Academy of Management Journal (1992), pp.1010-1035.

Min, B., 'Outside director’s board meeting attendance,' mimeo, (2011) Griffith University.

Min, B., 'Evaluation of board reform: An examination of the appointment of outside directors,' Journal of the Japanese and International Economies, (2013), 29, pp. 2143.

Min, B., and Verhoeven, P., 'Outsider board activity, ownership structure and firm value: Evidence from Korea,' International Review of Finance, 13 (2013), pp.187-214.

Min, B., and Smyth, R., 'Corporate governance, globalisation and firm productivity,' Journal of World Business, 49 (2014), pp. 372-385.

Min, B., and Bowman, G.J, 'Corporate governance, regulation and foreign equity ownership: Lessons from Korea,' Economic Modelling, 47 (2015), pp.145-155.

Mitton, T., 'A cross firm analysis of the impact of corporate governance on the East Asian financial crisis.’ Journal of Financial Economics 64 (2002), pp. 215-241.

Miyajima, H., 'The performance effects and determinants of reform.' in Aoki, M., Jackson, G., Miyajima, H. (eds.). Corporate Governance in Japan. (2008), Oxford University Press: New York.

Myers SC. and Majluf NS. 'Corporate financing and investment decisions when firms have information that investors do not have.' Journal of Financial Economics 13 (1984), pp.187-221.

Nakamura, M., 'Adoption and policy implications of Japan's new corporate governance practices after the reform.' Asia Pacific Journal of Management, 28, (2011), pp. 187213.

Organisation for Economic Co-operation and Development, Corporate Governance in Asia: A comparative perspective, (2001), Paris: OECD.

Payne, GT, Benson, GS, and Finegold DL., 'Corporate board attributes, team effectiveness and firm performance.' Journal of Management Studies. 46 (2009), pp.704-731.

Pearce II., JA and Jahra, SA. 'Board composition from a strategic contingency perspective,' Journal of Management Studies. 29 (2007), pp.417-438.

Peng M.W., Bhagat, R.S. Chang, S-J., 'Asia and global business,' Journal of International Business Studies, 41 (2010), pp. 373-376. 
Pfeffer, J., 'Size and composition of corporate boards of director: the organisation and its environment.' Administrative Science Quarterly 17 (1972), pp.218-229.

Pfeffer, J., 'Size, composition and function of hospital boards of directors: A study of organisation-environment linkage,' Administrative Science Quarterly. 18 (1973), pp.349-364.

Pfeffer, J. and Salancik, G.R., The External Control of Organisations: A Resource Dependence Perspectiv. (1978), Harper \& Row: New York.

Potter PB., 'Globalization and economic regulation in China: Selective adaptation of globalized norms and practices.' Washington University Global Studies Law Review, 2 (2003), 119-150.

Potter PB., 'Legal reform in China: Institutions, culture and selective adaptation'. Law and Social Inquiry 29(2), (2004), 465-495.

Ravasi, D. and Zattoni, A. 'Exploring the Political Side of Board Involvement in Strategy: A Study of Mixed-Ownership Institution.’ Journal of Management Studies 43 (2006), pp.1671-1702.

Raheja, C.G., 'Determinants of board size and composition: A theory of corporate boards.' Journal of Financial and Quantitative Analysis 40 (2005), pp. 283-306.

Romano, R., 'Corporate law and corporate governance,' Industrial and Corporate Change 5 (1996), 277-340.

Rutherford, MA., Buchholt,AK, and Brown, JA. 'Examining the relationship betweenmonitoring and incentives in corporate governance.' Journal of Management Studies 44 (2007), pp.414-430

Sanders, W.G. \& Tuschke, A.C., 'The adoption of institutionally contested organizational practices: the emergence of stock option pay in Germany,' Academy of Management Journal, 50, (2007), pp. 33-56.

Schaede, U., 'Understanding Corporate Governance in Japan: Do Classical Concepts Apply?' Industrial and Corporate Change 3 (1994), pp.285-327.

Yermack, D. 'Higher valuation of companies with a small Board of Directors.' Journal of Financial Economics 40 (1996), pp.185-212

Young MN. Peng MW. Ahlstrom D. Bruton GD. and Jiang Y. 'Corporate governance in emerging economies: A review of principal-principal perspective.' Journal of Management 45 (2008), pp.196-220.

Williamson, O.E., Markets and hierarchies: Analysis and anti-trust implications. (1975), New York: Free Press.

Williamson, O.E., The economic institutions of capitalism: Firms, markets, relational contracting. (1985), New York, NY: Free Press.

Wu, Yilin, 'Honey, I Shrunk the Board,' (2000), Working Paper, University of Chicago.

Zeitlin J, Herrigel G., Americanization and Its Limits: Reworking Us Technology and Management in Post-War Europe and Japan. (2000), Oxford: Oxford University Press. 
Table 1a: Election of Outside Directors: Corporations Listed on the Korea Exchange (\%)

\begin{tabular}{lccccccccc}
\hline & 1999 & 2000 & 2001 & 2002 & 2003 & 2004 & 2005 & 2006 & 2007 \\
\hline $\begin{array}{l}\text { Total Listed } \\
\text { Corporations }\end{array}$ & 100 & 100 & 100 & 100 & 100 & 100 & 100 & 100 & 100 \\
$\begin{array}{l}\text { Firms without } \\
\text { outside director }\end{array}$ & 66.0 & 37.7 & 34.6 & 29.6 & 22.4 & 23.6 & 17.9 & 17.6 & 5.7 \\
$\begin{array}{l}\text { Firms with at } \\
\text { least one outside }\end{array}$ & 34.0 & 62.3 & 65.4 & 70.4 & 77.6 & 76.4 & 82.1 & 82.4 & 94.3 \\
director & & & & & & & & & \\
$\begin{array}{l}\text { No. of outside } \\
\text { directors per firm }\end{array}$ & & & & & & & & & \\
$=1$ & 16.4 & 19.0 & 22.5 & 22.8 & 24.1 & 23.5 & 26.9 & 28.1 & 32.4 \\
$=2$ & 10.2 & 27.0 & 28.1 & 30.1 & 32.5 & 31.0 & 32.5 & 29.1 & 33.7 \\
$\geq 3$ & 7.3 & 16.3 & 14.7 & 17.5 & 21.1 & 22.0 & 22.8 & 25.2 & 28.1 \\
\hline
\end{tabular}

Note: The discrepancies, if any, between the total number at the bottom and in row 3 are due to rounding errors. Compilation was based on the KLCA database (Min and Smyth 2014). We dropped firms if the size of BOD is zero. This zero appointment figure could be overstated because the KLCA database treated missing values as zero appointment particularly during the early stage of the introduction of board regulations. We expect firms failed to comply with the regulations deliberately did not report.

Table 1b: Distribution of Board Size (Number, \%, 1999-2007)

\begin{tabular}{llllllllllllllll}
\hline BOD Size & 1 & 2 & 3 & 4 & 5 & 6 & 7 & 8 & 9 & 10 & 11 & 12 & 13 & $\begin{array}{l}14 \text { or } \\
\text { above }\end{array}$ & Total \\
\hline $\begin{array}{l}\text { Number } \\
\%\end{array}$ & 50 & 251 & 717 & 1,336 & 647 & 801 & 598 & 466 & 466 & 94 & 82 & 59 & 25 & 75 & 5,376 \\
\hline
\end{tabular}

BOD is winsorized as 14 (i.e., the top 1 percent). 
Graph 1. Trends in Board Size and Number of Outside Directors (1999-2007)

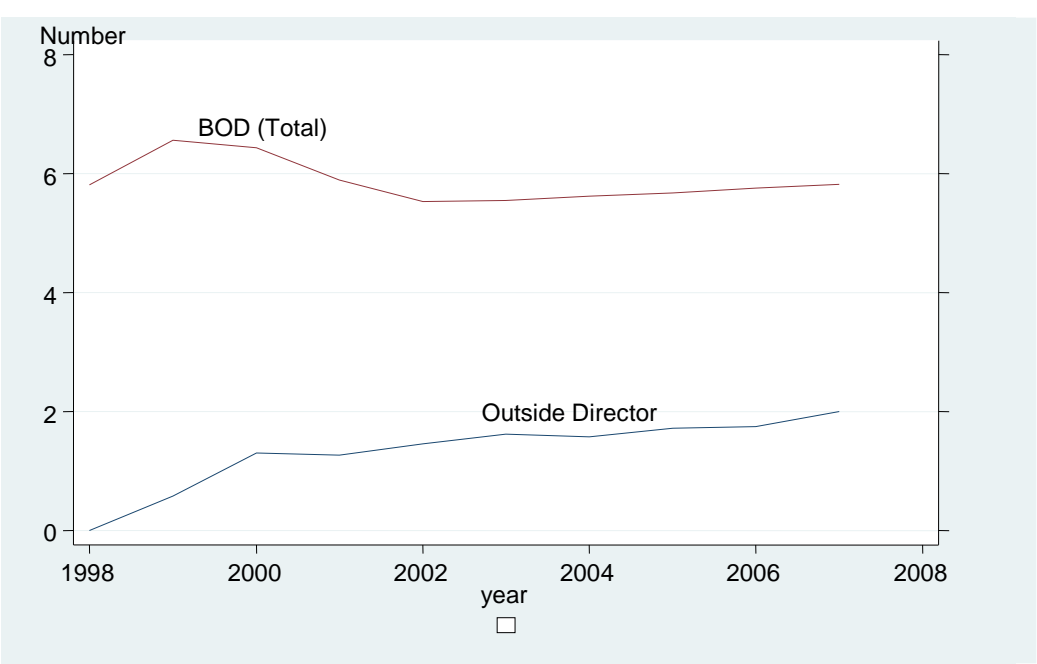

This graph shows trends in board size (top line) and number of outside directors (low line) during our sample period. Graphs are based on average values of listed industrial firms for each year.

Table 2. Distribution of Board Structure (Ratio of Outside Directors to Board) (Number, \%, 1999-2007)

\begin{tabular}{llllllll}
\hline Point Frequency & 0.0 & 0.25 & 0.33 & 0.50 & 0.67 & Total \\
\hline & 1,272 & 1,068 & 821 & 497 & 128 & 5,376 \\
& $23.66 \%$ & $19.87 \%$ & $15.27 \%$ & $9.24 \%$ & $2.38 \%$ & $100.00 \%$ \\
\hline \hline Interval Frequency & 0.0 & $(0.01,0.25)$ & $(0.26,0.33)$ & $(0.34,0.50)$ & $(0.51,0.67)$ & $(0.68,1.00)$ & Total \\
\hline & & & & & & & \\
& 1,272 & 1,267 & 1,219 & 1,038 & 436 & 144 & 5.376 \\
& $23.66 \%$ & $23.57 \%$ & $22.67 \%$ & $19.31 \%$ & $8.11 \%$ & $2.68 \%$ & \\
$\begin{array}{l}\text { Cumulative Interval } \\
\text { Frequency }\end{array}$ & $23.66 \%$ & $47.23 \%$ & $69.9 \%$ & $89.21 \%$ & $97.32 \%$ & $100.00 \%$ \\
\hline \hline
\end{tabular}

This table reports point frequency (upper panel), interval frequency (middle panel) and cumulative interval frequency (lower panel) of board structure, defined as the ratio of outside directors to board members. Figures in the upper and lower parts indicate observed numbers and percentages in total observations, respectively. Cumulative interval frequency is calculated based on the interval frequency.

This zero appointment figure could be overstated because the KLCA database treated missing values as zero appointment particularly during the early stage of the introduction of board regulations. We expect firms failed to comply with the regulations deliberately did not report. 
Table 3. Variable Definitions and Summary Statistics

\begin{tabular}{|c|c|c|c|c|c|c|c|c|c|}
\hline Variable & $\mathrm{N}$ & Mean & Median & $\begin{array}{l}\text { Standard } \\
\text { deviation }\end{array}$ & p25 & p75 & Min & Max & Definitions \\
\hline boardsize & 5376 & 5.50 & 5.00 & 4.43 & 4.00 & 7.00 & 1.00 & 14.00 & Total members of the board of directors \\
\hline seniority & 5344 & 34.12 & 35.00 & 6.85 & 32.19 & 37.80 & 0.00 & 75.50 & The age of firms from incorporation \\
\hline rnd2sale & 3881 & 0.02 & 0.01 & 0.13 & 0.00 & 0.02 & 0.00 & 7.69 & The ratio of R\&D expenses to sales \\
\hline machine2N & 5171 & 0.57 & 0.12 & 1.24 & 0.03 & 0.42 & -0.03 & 11.20 & The ratio of machine to employees \\
\hline lintangibleasset & 4551 & 13.23 & 13.3 & 2.94 & 11.33 & 15.2 & 0.69 & 22.00 & Natural logarithm of intangible assets \\
\hline lcapital & 5733 & 17.11 & 16.8 & 1.47 & 16.11 & 17.8 & 13.12 & 24.00 & Natural logarithm of capital \\
\hline Performance & 4891 & 0.00 & 0.02 & 1.00 & -0.34 & 0.36 & -13.58 & 32.10 & $\begin{array}{l}\text { Latent variable extracted by Principle Component } \\
\text { Factor Analysis using lag of the firm’s average } \\
\text { operating income scaled by sales in the previous } \\
\text { two years, lag of Tobin's Q (market value of } \\
\text { ordinary shares plus book value of debt divided by } \\
\text { book value of asset), inverse of volatility of share } \\
\text { return, calculated by monthly-based standard } \\
\text { deviation of share returns and continuously } \\
\text { compounded share return. }\end{array}$ \\
\hline Finandistress & 5713 & 0.09 & 0.00 & 0.29 & 0.00 & 0.00 & 0.00 & 1.00 & $\begin{array}{l}\text { A binary variable with a value of unity when a firm } \\
\text { had experienced net losses in the previous two year } \\
\text { consecutively and zero otherwise }\end{array}$ \\
\hline $\mathrm{CSH}$ & 5161 & 0.33 & 0.31 & 0.19 & 0.18 & 0.46 & 0.00 & 1.00 & Controlling shareholder’s equity ownership \\
\hline foreignshare & 5142 & 0.09 & 0.01 & 0.15 & 0.00 & 0.12 & 0.00 & 0.93 & Equity ownership owned by foreign investors \\
\hline Debt2equity & 5512 & 0.01 & 0.00 & 0.15 & 0.00 & 0.01 & 0.00 & 9.96 & The ratio of debt to equity \\
\hline
\end{tabular}

$\mathrm{N}$ denotes number of observations, p25 and p75 respectively refers to low and high quartiles. 
Table 4. Benchmark Estimation Results for Board Size (Unrestricted sample)

\begin{tabular}{|c|c|c|c|c|c|c|c|c|}
\hline & (1) & (2) & (3) & (4) & (5) & (6) & (7) & (8) \\
\hline rnd2sale & $\begin{array}{l}0.051^{* * *} \\
{[0.002]}\end{array}$ & & & & $\begin{array}{c}\odot .049^{* * *} \\
{[0.003]}\end{array}$ & & & \\
\hline machine2N & & $\begin{array}{c}0.044^{* * *} \\
{[\odot .000]}\end{array}$ & & & & $\begin{array}{c}0.042^{* * *} \\
{[\odot .000]}\end{array}$ & & \\
\hline lintangible & & & $\begin{array}{c}0.047^{* * *} \\
{[0.000]}\end{array}$ & & & & $\begin{array}{c}0.046^{* * *} \\
{[0.000]}\end{array}$ & \\
\hline lcapital & & & & $\begin{array}{c}0.094^{* * *} \\
{[\odot .000]}\end{array}$ & & & & $\begin{array}{c}0.088^{* * *} \\
{[\odot .000]}\end{array}$ \\
\hline Seniority & $\begin{array}{c}0.096^{* * *} \\
{[0.001]}\end{array}$ & $\begin{array}{c}0.107^{* * *} \\
{[0.000]}\end{array}$ & $\begin{array}{c}0.050^{* *} \\
{[0.046]}\end{array}$ & $0.083^{* * *}$ & $\begin{array}{c}0.097^{* * *} \\
{[0.001]}\end{array}$ & $0.106^{* * *}$ & $\begin{array}{l}0.049^{* *} \\
\end{array}$ & $\begin{array}{c}0.080^{* * *} \\
{[0.000]}\end{array}$ \\
\hline $\mathrm{CSH}$ & $-0.144^{*}$ * & $-0.155^{\text {** }}$ & $-0.156^{* *}$ & $\begin{array}{c}-0.121^{*} \\
0.037\end{array}$ & $-0.137^{*}$ & $-0.150^{* *}$ & $-0.148^{* *}$ & $-0.114^{*}$ \\
\hline findistress & $-0.182^{\star \star *}$ & $\begin{array}{l}{[0.015]} \\
-0.178^{* * *}\end{array}$ & $\begin{array}{l}{[0.011]} \\
-0.164^{* *}\end{array}$ & $\begin{array}{l}{[0.037]} \\
-0.155^{* * *}\end{array}$ & $\begin{array}{l}{[0.059]} \\
-0.197^{* *}\end{array}$ & $\begin{array}{l}{[0.019]} \\
-0.194^{\star * *}\end{array}$ & $\begin{array}{l}{[0.017]} \\
-0.175^{* * *}\end{array}$ & $\begin{array}{l}{[0.054]} \\
-0.162^{* * *}\end{array}$ \\
\hline Performance & $\begin{array}{c}{[0.000]} \\
-0.013\end{array}$ & $\begin{array}{c}{[0.000]} \\
-0.014\end{array}$ & $\begin{array}{c}{[0.000]} \\
-0.013\end{array}$ & $\begin{array}{c}{[0.000]} \\
-0.024\end{array}$ & $\begin{array}{c}{[0.000]} \\
-0.010\end{array}$ & $\begin{array}{c}{[0.000]} \\
-0.013\end{array}$ & $\begin{array}{l}{[0.000]} \\
-0.013\end{array}$ & $\begin{array}{l}{[0.000]} \\
-0.027^{* *}\end{array}$ \\
\hline & {$[0.523]$} & {$[0.257]$} & {$[0.308]$} & {$[0.062]$} & {$[0.611]$} & {$[0.305]$} & {$[0.328]$} & {$[0.048]$} \\
\hline foreignshare & $\begin{array}{c}0.004^{* * *} \\
{[0.000]}\end{array}$ & $\begin{array}{l}0.003^{* * *} \\
{[\odot .000]}\end{array}$ & $\begin{array}{l}0.002^{* *} \\
{[0.018]}\end{array}$ & $\begin{array}{l}0.002^{* *} \\
{[0.032]}\end{array}$ & $\begin{array}{l}0.004^{* * *} \\
{[0.000]}\end{array}$ & $\begin{array}{l}0.003^{* * *} \\
{[\odot . \odot 0 \odot]}\end{array}$ & $\begin{array}{l}0.002^{* * *} \\
{[0.004]}\end{array}$ & $\begin{array}{c}\odot .001^{* *} \\
{[\odot .048]}\end{array}$ \\
\hline debt2equity & $\begin{array}{l}-0.068^{* * *} \\
{[0.000]}\end{array}$ & $\begin{array}{l}-0.075^{* * *} \\
{[0.001]}\end{array}$ & $\begin{array}{l}-0.069^{* * *} \\
{[0.000]}\end{array}$ & $\begin{array}{l}-0.071^{* * *} \\
{[0.000]}\end{array}$ & $\begin{array}{l}-0.072^{* * *} \\
{[0.000]}\end{array}$ & $\begin{array}{l}-0.076^{* * *} \\
{[0.000]}\end{array}$ & $\begin{array}{l}-0.069^{* * *} \\
{[0.000]}\end{array}$ & $\begin{array}{l}-0.070^{* *} \\
{[0.001]}\end{array}$ \\
\hline _cons & $\begin{array}{l}1.289^{* * *} \\
{[0.000]}\end{array}$ & $\begin{array}{l}1.268^{* * *} \\
{[\odot .000]}\end{array}$ & $\begin{array}{l}0.931^{* * *} \\
{[\odot .000]}\end{array}$ & $\begin{array}{l}-0.216 \\
{[0.302]}\end{array}$ & $\begin{array}{l}1.400^{* * *} \\
{[0.000]}\end{array}$ & $\begin{array}{l}1.323^{* * *} \\
{[\odot .000]}\end{array}$ & $\begin{array}{l}1.005^{* * *} \\
{[0.000]}\end{array}$ & $\begin{array}{r}-0.072 \\
{[0.664]}\end{array}$ \\
\hline Year effect & Yes & Yes & Yes & Yes & Yes & Yes & Yes & Yes \\
\hline Industry effect & Yes & Yes & Yes & Yes & No & No & No & No \\
\hline $\mathrm{N}$ & 3317.000 & 4280.000 & 3644.000 & 4561.000 & 3317.000 & $4280.0 \odot \odot$ & 3644.000 & $4561.0 \odot \odot$ \\
\hline r2_p & 0.020 & 0.021 & 0.037 & 0.036 & 0.015 & 0.018 & 0.033 & 0.032 \\
\hline
\end{tabular}

This table reports the Poisson estimates for the unrestricted sample firms' board size: the dependent variable (bod_total) is total board members. Columns (1)-(4) include both year and industry effects whereas columns (5)-(8) include only year effect. Rnd2sale is R\&D expenses scaled by sales; machine2N refers to expenditure on machines scaled by number of employees; lintangible is (natural) logarithm of intangible assets; lcapital is log of capital; seniority is proxied by the firm's age since incorporation; CSH is controlling shareholders equity ownership; Performance is a latent variable extracted from the Principle Component Analysis using four performance-related variables: the firm's average operating income scaled by sales in the previous two years, Tobin's $Q$, calculated by (market value of ordinary shares plus book value of debt) divided by book value of assets; inverse of volatility of share return, calculated by monthly-based standard deviation of share return; and continuously compounded share return. foreignshare is equity ownership held by foreign investors; c calculated by is calculat

$* * *, * *$ and $*$ denote (two-tailed) significance at $1 \%, 5 \%$ and $10 \%$, respectively. P-values are in brackets. P-values are based on cluster-adjusted standard error. $r 2$ p refers to pseudo $r 2$ 
Table 5: Estimation Results of Board Size between Chaebol Affiliates and Stand-alone Firms

\begin{tabular}{|c|c|c|c|c|c|c|c|c|}
\hline & \multicolumn{4}{|c|}{ Chaebol affiliates } & \multicolumn{4}{|c|}{ Stand-alone firms } \\
\hline & $(1)$ & (2) & $(3)$ & $(4)$ & $(5)$ & $(6)$ & $(7)$ & $(8)$ \\
\hline \multirow[t]{2}{*}{ rnd2sale } & $1.020^{* *}$ & & & & $0.045^{* * *}$ & & & \\
\hline & {$[0.012]$} & & & & {$[\odot . \odot \odot \odot]$} & & & \\
\hline \multirow[t]{2}{*}{ machine2N } & & $0.030^{*}$ & & & & $0.039 * * *$ & & \\
\hline & & {$[\odot .087]$} & & & & {$[0.007]$} & & \\
\hline \multirow[t]{2}{*}{ lintangible } & & & $0.054 * * *$ & & & & $\odot .036^{* * *}$ & \\
\hline & & & {$[\odot . \odot \odot \odot]$} & & & & {$[\odot .000]$} & \\
\hline \multirow[t]{2}{*}{ lcapital } & & & & $0.105^{* * *}$ & & & & $0.082^{* * *}$ \\
\hline & & & & {$[0.000]$} & & & & {$[0.000]$} \\
\hline \multirow[t]{2}{*}{ Seniority } & 0.050 & 0.053 & 0.02 & $\odot .028$ & $0.123^{* * *}$ & 0.134 *** & $0.062^{*}$ & $0.110^{* * *}$ \\
\hline & {$[\odot .216]$} & {$[0.156]$} & {$[\odot .542]$} & {$[0.351]$} & {$[\odot . \odot \odot 1]$} & {$[\odot . \odot \odot \odot]$} & {$[\odot . \odot 82]$} & {$[\odot . \odot \odot \odot]$} \\
\hline $\mathrm{CSH}$ & $-0.25^{* *}$ & $-\odot .28^{* *}$ & $-0.27^{* *}$ & $-0.18^{* *}$ & $-\odot .140^{*}$ & $-0.13^{*}$ & $-0.122^{*}$ & -0.100 \\
\hline \multirow{3}{*}{$\begin{array}{l}\text { Financial- } \\
\text { distress }\end{array}$} & {$[0.044]$} & {$[0.017]$} & {$[0.011]$} & {$[0.042]$} & {$[\odot .079]$} & {$[0.062]$} & {$[\odot .089]$} & {$[0.108]$} \\
\hline & -0.100 & $-0.14 * *$ & $-0.13^{* *}$ & $-0.11^{* *}$ & $-0.173^{* * *}$ & $-0.16^{* * *}$ & $-0.153^{* * *}$ & $-0.153^{* * *}$ \\
\hline & {$[0.156]$} & {$[0.018]$} & {$[0.030]$} & {$[\odot .023]$} & {$[\odot . \odot \odot \odot]$} & {$[\odot . \odot \odot \odot]$} & {$[\odot . \odot \odot \odot]$} & {$[\odot . \odot \odot \odot]$} \\
\hline \multirow[t]{2}{*}{ Performance } & $\odot .030$ & $\odot .026$ & 0.010 & -0.004 & $-\odot .050^{* *}$ & $-0.040^{*}$ & $-\odot .026^{*}$ & $-0.001 * *$ \\
\hline & {$[0.252]$} & {$[0.256]$} & {$[0.707]$} & {$[\odot .830]$} & {$[0.031]$} & {$[\odot .074]$} & {$[\odot . \odot 80]$} & {$[0.050]$} \\
\hline \multirow[t]{2}{*}{ foreignshare } & $0.05^{* * *}$ & $0.05^{* * *}$ & $0.03^{* *}$ & $0.03^{* * *}$ & 0.002 & 0.001 & 0.001 & 0.001 \\
\hline & {$[\odot . \odot \odot \odot]$} & {$[\odot . \odot \odot \odot]$} & {$[0.014]$} & {$[\odot .001]$} & {$[0.319]$} & {$[0.411]$} & {$[0.545]$} & {$[0.846]$} \\
\hline \multirow[t]{2}{*}{ debt2equity } & $-\odot .690^{*}$ & $-0.54^{* *}$ & $-0.52^{* *}$ & $-0.36^{*}$ & $-0.05^{* * *}$ & $-0.06 * * *$ & $-0.05^{* * *}$ & $-\odot .05^{* * *}$ \\
\hline & {$[0.100]$} & {$[0.043]$} & {$[0.015]$} & {$[\odot .071]$} & {$[\odot . \odot \odot \odot]$} & {$[\odot . \odot \odot \odot]$} & {$[\odot . \odot \odot \odot]$} & {$[0.000]$} \\
\hline \multirow[t]{2}{*}{ _cons } & $1.45^{* * *}$ & $1.45^{* * *}$ & $1.05^{* * *}$ & -0.371 & $1.272^{\star \star *}$ & $1.238^{* * *}$ & $0.989^{* * *}$ & $-\odot . \odot \odot 1$ \\
\hline & {$[\odot . \odot \odot \odot]$} & {$[\odot . \odot \odot \odot]$} & {$[\odot . \odot \odot \odot]$} & {$[0.171]$} & {$[\odot . \odot \odot \odot]$} & {$[\odot . \odot \odot \odot]$} & {$[\odot . \odot \odot \odot]$} & {$[\odot .900]$} \\
\hline \multirow{2}{*}{$\begin{array}{l}\text { Year effect } \\
\text { Industry } \\
\text { effect }\end{array}$} & Yes & Yes & Yes & Yes & Yes & Yes & Yes & Yes \\
\hline & Yes & Yes & Yes & Yes & Yes & Yes & Yes & Yes \\
\hline$N$ & 909.00 & $1227 . \odot \odot$ & $1079 . \odot \odot$ & $1330 . \odot \odot$ & $2408 . \odot \odot$ & 3053.00 & $2565 . \odot \odot$ & $3231 . \odot \odot$ \\
\hline$r 2 p$ & 0.03 & 0.031 & 0.06 & 0.055 & 0.026 & 0.02 & 0.031 & 0.03 \\
\hline
\end{tabular}


This table reports the Poisson estimates of board size for Chaebol affiliate (Columns 1-4) and stand-alone firms (Columns 5-8): the dependent variable (bod_total) is total board members. Rnd2sale is R\&D expenses scaled by sales; machine2N refers to expenditure on machines scaled by number of employees; lintangible is (natural) income scaled by sales in the previous two years, Tobin's 0 , calculated by (market value of ordinary shares plus book value of debt) divided by book value of assets: inverse of volatility of share return, calculated by monthly-based standard deviation of share return; and continuously compounded share return. foreignshare is equity ownership held by foreign investors; debt2equity is calculated by book value of debt scaled by equity; and findistress is unity when a firm had experienced consecutive net losses in the previous two years and zero otherwise.

$* * *, * *$ and $*$ denote (two-tailed) significance at $1 \%, 5 \%$ and $10 \%$, respectively. P-values are in brackets. P-values are based on cluster-adjusted standard error. r2_p refers to pseudo $r 2$ 
Table 6. Determinants of Board Size for Actively and Passively Adaptive Firms (the 25 percent rule)

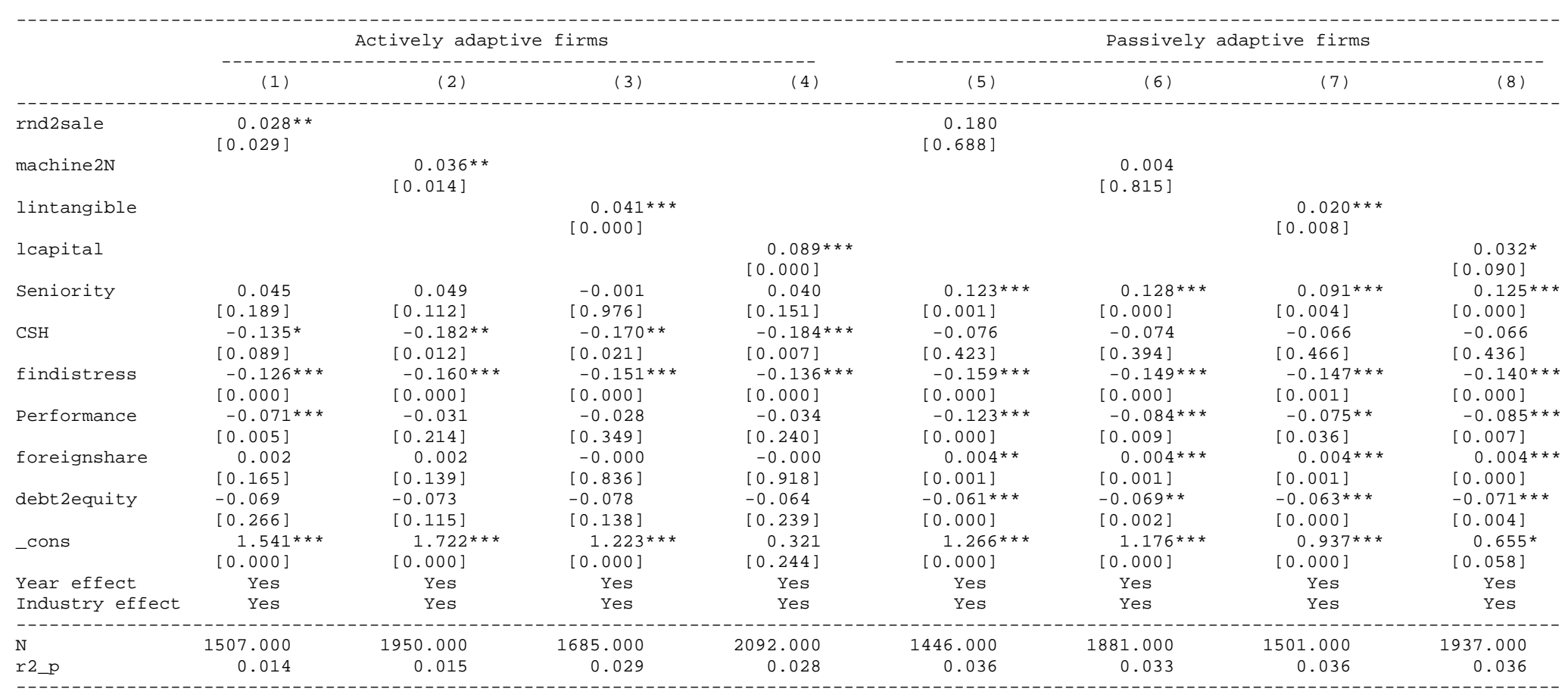

This table reports Poisson estimates of board size for actively adaptive firms (Columns 1-4) and passively adaptive firms (Columns 5-8): the dependent variable (bod_total) is total board members. The actively (passively) adaptive firms are defined as firms that appointed outside directors to at least (less than) 25 percent of board positions and with an asset size of no more than 2 trillion won ( 2 billion USD). All estimations include both year and industry enfects. Rnd2sale is R\&D expenses scaled by sales; machine2N refers to expenditure on machines scaled by number of employees; lintangible is (natural) logarithm of intangible assets; Icapital is log of capital; Seniority is proxied by the firm's age since incorporation; CsH is controlling shareholders equity ownership; Performance is a latent variable extracted from the Principle Component Analysis using four performance-related variables: the firm's average operating income scaled by sales in the previous two years, Tobin's $Q$, based standard deviation of share return; and conting by book value of debt scaled by equity; and findistress is a unity when a firm had experienced consecutive net losses in the previous two years and zero otherwise.

$* * *, * *$ and * denote (two-tailed) significance at $1 \%, 5 \%$ and $10 \%$, respectively. P-values are in brackets. P-values are based on cluster-adjusted standard error. r2_p refers to pseudo $r 2$ 
Table 7. Three-year Averaged Determinants of Board Size for Actively and Passively Adaptive Firms (the 25 percent rule)

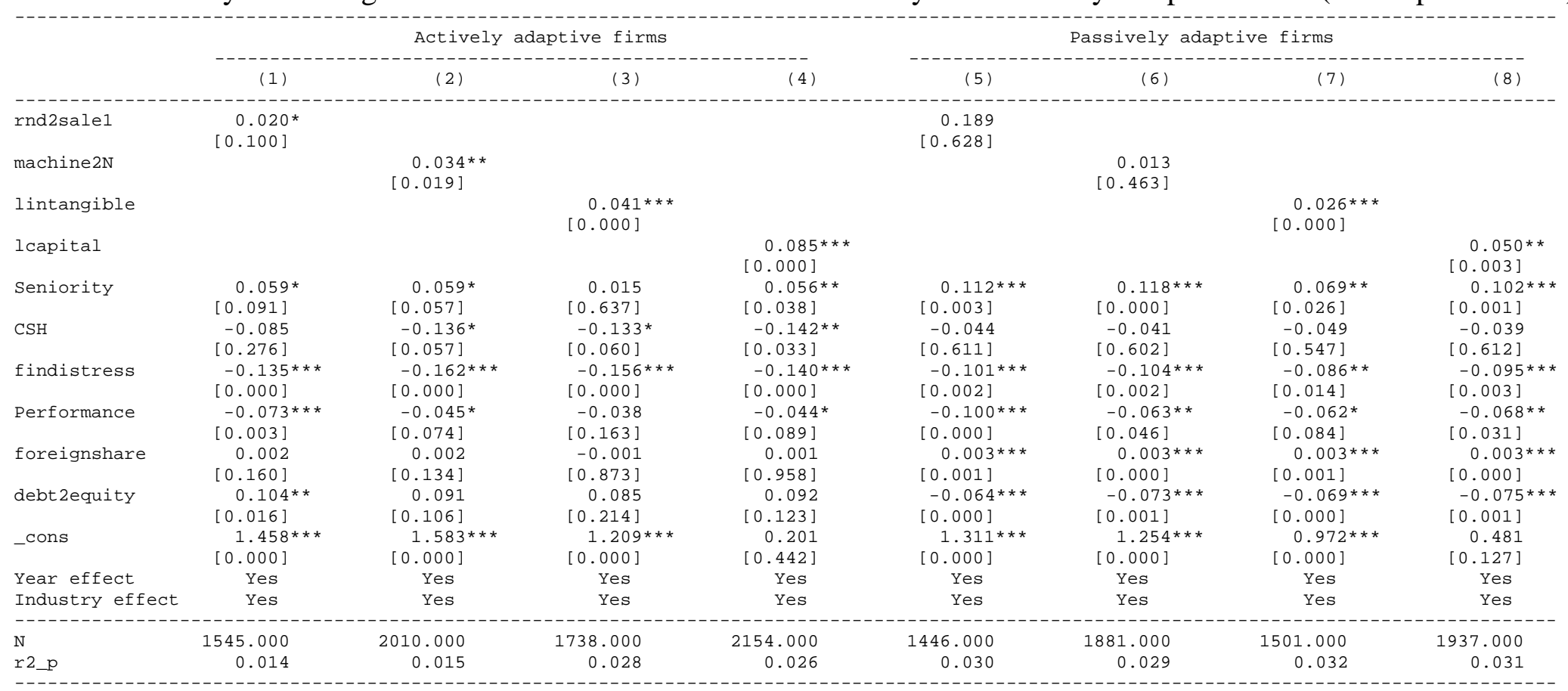

This table reports Poisson estimates of board size for actively adaptive firms (Columns 1-4) and passively adaptive firms (Columns 5 -8): the dependent variable (bod_total_3avg) is three-year-averaged total board members. The actively (passively) adaptive firms are defined as firms that appointed outside directors to at least (less than) 25 percent of board positions and have an asset size of no more than 2 trillion won ( 2 billion USD). All estimations include both year and industry effects. Rnd2sale is RaD expenses scaled by sales, machine2N refers to expenditure on machines scaled by number of employees, lintangible is (natural) logarithm of intangible asets, lcapital is log of capital; seniority is proxicd by the previous two years, Tobin's 0 calculated by (market valuf of ordinary shares plus book value of debt) divided by book value of assets; inverse of volatility of share return, calculated by monthly-based standard deviation of share return. and continuously compounded share return. foreignshare is one-lagged equity ownership held by foreign investors; debt2equity is calculated by book value of debt scaled by equity; and findistress is unity when a firm had experienced consecutive net losses in the previous two years and zero otherwise.

$* * *, * *$ and $*$ denote (two-tailed) significance at $1 \%, 5 \%$ and $10 \%$, respectively. P-values are in brackets. P-values are based on cluster-adjusted standard error. r2_p reférs to pseudo $r$. 
Table 8. MLE Estimates of the Determinants of Board Size for Actively vs. Passively Adaptive Firms (the 25 percent rule)

\begin{tabular}{|c|c|c|c|c|c|c|c|c|}
\hline & & Actively & aptive firms & & & Passively ada & ve firms & \\
\hline & (1) & (2) & (3) & (4) & (5) & (6) & (7) & (8) \\
\hline rnd2sale & $\begin{array}{c}0.031 \\
{[0.530]}\end{array}$ & & & & $\begin{array}{c}0.206 \\
{[0.672]}\end{array}$ & & & \\
\hline machine2N & & $\begin{array}{c}0.033^{* *} \\
{[0.013]}\end{array}$ & & & & $\begin{array}{r}-0.004 \\
{[0.830]}\end{array}$ & & \\
\hline lintangible & & & $\begin{array}{c}0.033^{* * *} \\
{[0.000]}\end{array}$ & & & & $\begin{array}{c}0.016^{* *} \\
{[0.010]}\end{array}$ & \\
\hline lcapital & & & & $\begin{array}{c}0.085^{* * *} \\
{[\odot .00 \Theta]}\end{array}$ & & & & $\begin{array}{c}0.036^{* *} \\
{[0.015]}\end{array}$ \\
\hline Seniority & $\begin{array}{r}0.038 \\
{[0.172]}\end{array}$ & $\begin{array}{c}0.043^{*} \\
{[0.085]}\end{array}$ & $\begin{array}{r}0.009 \\
{[0.708]}\end{array}$ & $\begin{array}{c}0.041^{*} \\
{[0.078]}\end{array}$ & $\begin{array}{c}0.096^{* * *} \\
{[0.003]}\end{array}$ & $\begin{array}{l}0.109^{* * *} \\
{[0.000]}\end{array}$ & $\begin{array}{l}\Theta .079^{* * *} \\
{[0.009]}\end{array}$ & $\begin{array}{l}0.109^{* * *} \\
{[0.000]}\end{array}$ \\
\hline $\mathrm{CSH}$ & $\begin{array}{r}-0.111 \\
{[0.145]}\end{array}$ & $\begin{array}{l}-0.148^{* *} \\
{[0.034]}\end{array}$ & $\begin{array}{l}-0.162^{* *} \\
{[0.024]}\end{array}$ & $\begin{array}{l}-0.168^{* *} \\
{[0.010]}\end{array}$ & $\begin{array}{r}-0.102 \\
{[0.248]}\end{array}$ & $\begin{array}{r}-0.095 \\
{[0.220]}\end{array}$ & $\begin{array}{r}-0.077 \\
{[\odot .353]}\end{array}$ & $\begin{array}{r}-0.086 \\
{[0.251]}\end{array}$ \\
\hline findistress & $-0.071^{*}$ & $-0.097^{* *}$ & $-0.099^{* *}$ & $-0.085^{* *}$ & $-0.147^{\star * \star}$ & $-0.117^{* *}$ & $-0.124^{* *}$ & $-0.108^{* *}$ \\
\hline dev_perform & $\begin{array}{r}{[0.100]} \\
-0.038\end{array}$ & $\begin{array}{c}{[0.016]} \\
-0.009\end{array}$ & $\begin{array}{r}{[0.023]} \\
0.005\end{array}$ & $\begin{array}{r}{[0.027]} \\
-0.003\end{array}$ & $\begin{array}{l}{[0.004]} \\
-0.071^{* *}\end{array}$ & $\begin{array}{c}{[0.010]} \\
-0.031\end{array}$ & $\begin{array}{c}{[0.012]} \\
-0.031\end{array}$ & $\begin{array}{l}{[0.013]} \\
-0.031\end{array}$ \\
\hline & {$[0.140]$} & {$[0.553]$} & {$[0.756]$} & {$[0.852]$} & {$[0.011]$} & {$[0.137]$} & {$[0.190]$} & {$[0.133]$} \\
\hline mn_perform & $\begin{array}{l}-0.091^{* * *} \\
{[0.009]}\end{array}$ & $\begin{array}{c}-0.060^{* *} \\
{[0.026]}\end{array}$ & $\begin{array}{l}-0.070^{* * *} \\
{[0.008]}\end{array}$ & $\begin{array}{l}-0.066^{* *} \\
{[0.010]}\end{array}$ & $\begin{array}{c}-0.154^{* * *} \\
{[0.000]}\end{array}$ & $\begin{array}{c}-0.122^{* * *} \\
{[0.000]}\end{array}$ & $\begin{array}{c}-0.105^{\star * *} \\
{[0.003]}\end{array}$ & $\begin{array}{c}-0.122^{\star \star \star} \\
{[0.000]}\end{array}$ \\
\hline foreignshare & 0.001 & 0.001 & $-\odot .000$ & $-\odot .000$ & 0.002 & 0.002 & $0.002^{*}$ & $0.0 \odot 2^{*}$ \\
\hline & {$[0.384]$} & {$[0.379]$} & {$[0.830]$} & {$[0.916]$} & {$[0.106]$} & {$[0.103]$} & {$[\odot .058]$} & {$[0.079]$} \\
\hline debt2equity & -0.121 & -0.087 & -0.095 & -0.065 & -0.054 & -0.050 & -0.054 & -0.050 \\
\hline & $[0,408]]^{* * *}$ & $[0.464]]^{*}$ & {$[0.422]$} & {$[0.578]$} & $[0.389]]_{* \star *}$ & {$[0.415]$} & {$[0.391]$} & {$[0.415]$} \\
\hline _cons & $\begin{array}{c}1.560^{* * *} \\
{[\odot .000]}\end{array}$ & $\begin{array}{c}1.716^{* * *} \\
{[\odot .000]}\end{array}$ & $\begin{array}{c}1.300^{* * *} \\
{[\odot .000]}\end{array}$ & $\begin{array}{r}0.353 \\
{[0.186]}\end{array}$ & $\begin{array}{c}1.314^{* * *} \\
{[\odot .000]}\end{array}$ & $\begin{array}{c}1.243^{* * *} \\
{[\odot .000]}\end{array}$ & $\begin{array}{c}1.068^{* * *} \\
{[\odot .00 \odot]}\end{array}$ & $\begin{array}{c}0.652^{*} \\
{[0.041]}\end{array}$ \\
\hline Year effect & Yes & Yes & Yes & Yes & Yes & Yes & Yes & Yes \\
\hline Industry effect & Yes & Yes & Yes & Yes & Yes & Yes & Yes & Yes \\
\hline N & 1507.000 & 1950.000 & 1685.000 & 2092.000 & 1446.000 & 1881.000 & 1501.000 & 1937.000 \\
\hline 11 & -3171.803 & -4063.709 & -3522.326 & -4348.108 & -2940.495 & -3787.392 & -3045.286 & -3896.608 \\
\hline Prob $>\chi^{2}($ & 0.117 & 0.086 & 0.012 & 0.028 & 0.041 & 0.014 & 0.069 & 0.013 \\
\hline
\end{tabular}

This table reports MLE estimates of board size for actively adaptive firms (Columns 1-4) and passively adaptive firms (Columns 5 -8): the dependent variable (bod total) is (integer) total board members. The actively (passively) adaptive firms are defined as firms that appointed outside directors to at least (less than) 25 percent of board positions and with an asset size of no more than 2 trillion won ( 2 billion USD). All estimations include both year and industry effects. Rnd2sale is R\&D expenses proxied by the firm's age since incorporation; lcapital is log of capital; CSH is controlling shareholders' equity ownership. Dev perform and mn perform respectively refers to (firm-level) demeaned Performance and mean of the Performance, where Performance is a latent variable extracted from the Principle Component Analysis using four performance-related variables: the firm's average operating income scaled by sales in the previous two years, Tobin's $Q$, calculated by (market value of ordinary shares plus book value of debt) divided by book value of assets, inverse of volatility of share return, calculated by monthly-based standard deviation of share return; and continuously compounded share return. foreignshare is one-lagged equity ownership held by foreign investors; debt2equity is calculated by book value of debt scaled by equity; and findistress is unity when a firm had experienced consecutive net losses in the previous two years and zero otherwise,

$* * *, * *$ and * denote (two-tailed) significance at $1 \%, 5 \%$ and $10 \%$, respectively. P-values are in brackets. P-values are based on cluster-adjusted standard error. Ll refers to $\log$ likelihood and Prob $>\chi^{2}(1)$ indicates probabilities in relation to the null hypothesis that estimated coefficients of dev_perform and dev_perform are equal. 
Table 9. Negative Binomial Estimates of Determinants of Board Size for Actively vs. Passively Adaptive Firms (the 25 percent rule)

\begin{tabular}{|c|c|c|c|c|c|c|c|c|}
\hline & & Actively & daptive firms & & & Passively a & ptive firms & \\
\hline & (1) & (2) & (3) & (4) & (5) & (6) & (7) & (8) \\
\hline rnd2sale & $\begin{array}{c}0.028^{* *} \\
{[0.029]}\end{array}$ & & & & $\begin{array}{r}0.180 \\
{[0.688]}\end{array}$ & & & \\
\hline machine2N & & $\begin{array}{c}0.036^{* *} \\
{[\odot .014]}\end{array}$ & & & & $\begin{array}{r}0.004 \\
{[0.815]}\end{array}$ & & \\
\hline lintangible & & & $\begin{array}{c}\Theta . \odot 41^{* * *} \\
{[\odot .00 \odot]}\end{array}$ & & & & $\begin{array}{c}0.020^{* * *} \\
{[0.008]}\end{array}$ & \\
\hline lcapital & & & & $\begin{array}{c}\odot . \odot 89^{* * *} \\
{[\odot .000]}\end{array}$ & & & & $\begin{array}{c}\odot .032^{*} \\
{[\odot .090]}\end{array}$ \\
\hline Seniority & $\begin{array}{r}0.045 \\
{[\odot .189]}\end{array}$ & $\begin{array}{r}0.049 \\
{[\odot .112]}\end{array}$ & $\begin{array}{r}-\odot .001 \\
{[\odot .976]}\end{array}$ & $\begin{array}{r}0.040 \\
{[0.151]}\end{array}$ & $\begin{array}{c}0.123^{* * *} \\
{[0.001]}\end{array}$ & $\begin{array}{c}0.128^{* * *} \\
{[0.000]}\end{array}$ & $\begin{array}{c}\odot .091^{* * *} \\
{[\odot .004]}\end{array}$ & $\begin{array}{l}0.125^{\star * *} \\
{[0.000]}\end{array}$ \\
\hline $\mathrm{CSH}$ & $\begin{array}{l}-0.135^{*} \\
{[0.089]}\end{array}$ & $\begin{array}{l}-0.182^{* *} \\
{[0.012]}\end{array}$ & $\begin{array}{l}-0.170^{\star *} \\
{[\odot . \Theta 21]}\end{array}$ & $\begin{array}{l}-0.184^{\star * *} \\
{[0.007]}\end{array}$ & $\begin{array}{r}-0.076 \\
{[0.423]}\end{array}$ & $\begin{array}{r}-0.074 \\
{[0.394]}\end{array}$ & $\begin{array}{r}-0.066 \\
{[0.466]}\end{array}$ & $\begin{array}{r}-0.066 \\
{[0.436]}\end{array}$ \\
\hline findistress & $\begin{array}{l}-0.126^{* * *} \\
{[0.000]}\end{array}$ & $\begin{array}{l}-0.160^{* * *} \\
{[0.000]}\end{array}$ & $\begin{array}{l}-0.151^{* * *} \\
{[\odot .00 \odot]}\end{array}$ & $\begin{array}{l}-0.136^{* * *} \\
{[0.000]}\end{array}$ & $\begin{array}{l}-\odot .159^{* * *} \\
{[\odot .000]}\end{array}$ & $\begin{array}{l}-0.149^{* * *} \\
{[\odot . \odot \odot \odot]}\end{array}$ & $\begin{array}{l}-0.147^{* * *} \\
{[0.001]}\end{array}$ & $\begin{array}{l}-0.140^{* *} \\
{[0.000]}\end{array}$ \\
\hline Performance & $\begin{array}{l}-0.071^{* * *} \\
{[0.005]}\end{array}$ & $\begin{array}{r}-0.031 \\
{[0.214]}\end{array}$ & $\begin{array}{r}-0.028 \\
{[0.349]}\end{array}$ & $\begin{array}{r}-0.034 \\
{[0.240]}\end{array}$ & $\begin{array}{l}-0.123^{* * *} \\
{[0.000]}\end{array}$ & $\begin{array}{l}-0.084^{* * *} \\
{[0.009]}\end{array}$ & $\begin{array}{l}-0.075^{* *} \\
{[0.036]}\end{array}$ & $\begin{array}{l}-0.085^{* * *} \\
{[0.007]}\end{array}$ \\
\hline foreignshare & $\begin{array}{r}0.002 \\
{[0.165]}\end{array}$ & $\begin{array}{r}0.002 \\
{[0.139]}\end{array}$ & $\begin{array}{r}-0.000 \\
{[0.836]}\end{array}$ & $\begin{array}{r}-0.000 \\
{[0.9181}\end{array}$ & $0.004^{* * *}$ & $0.004^{*}$ * * & $0.004^{*}$ * * & $0.004^{*}$ * \\
\hline debt2equity & -0.069 & -0.073 & -0.078 & -0.064 & $-0.061^{* * *}$ & $-0.069^{* * *}$ & $-0.063^{* * *}$ & $-0.071^{* \text { * * }}$ \\
\hline & {$\left[\begin{array}{c}{[0.266]} \\
1.541^{* * *}\end{array}\right.$} & $\begin{array}{c}{[0.115]} \\
1.722^{* * *}\end{array}$ & {$\left[\begin{array}{c}{[0.138]} \\
1.223^{* *}\end{array}\right.$} & $\begin{array}{r}{[0.239]} \\
0.321\end{array}$ & $\begin{array}{c}{[0.000]} \\
1.266^{* * *}\end{array}$ & {$\left[\begin{array}{c}{[0.002]} \\
1.176^{* * *}\end{array}\right.$} & $[0.000]][0$ & {$[0.004]$} \\
\hline _cons & $\begin{array}{l}1.541^{* * *} \\
{[0.000]}\end{array}$ & $\begin{array}{c}1.722^{\star * *} \\
{[0.000]}\end{array}$ & $\begin{array}{l}1.223^{* * *} \\
{[0.000]}\end{array}$ & $\begin{array}{r}0.321 \\
{[0.244]}\end{array}$ & $\begin{array}{c}1.266^{* * *} \\
{[0.000]}\end{array}$ & $\begin{array}{c}1.176^{* * *} \\
{[0.000]}\end{array}$ & $\begin{array}{c}0.937^{* * *} \\
{[0.000]}\end{array}$ & $\begin{array}{r}0.655 \\
{[0.058]}\end{array}$ \\
\hline Year effect & Yes & Yes & Yes & Yes & Yes & Yes & Yes & Yes \\
\hline Industry effect & Yes & Yes & Yes & Yes & Yes & Yes & Yes & Yes \\
\hline N & $15 \odot 7.000$ & $1950.0 \odot \odot$ & 1685.000 & $2092.00 \odot$ & 1446.000 & 1881.000 & $1501.00 \odot$ & 1937.000 \\
\hline alpha & 0.000 & 0.000 & 0.000 & 0.000 & 0.000 & 0.000 & 0.000 & 0.000 \\
\hline 11 & -3275.527 & -4203.089 & -3618.456 & -4465.319 & -3025.768 & -3900.203 & -3118.253 & -4006.039 \\
\hline
\end{tabular}

This table reports the Negative Binomial estimates of board size for actively adaptive firms (Columns 1-4) and passively adaptive firms (Columns $5-8$ ): the dependent variable (bod total) is total board members. The actively (passively) adaptive firms are defined as firms that appointed outside directors to at least (less than) 25 percent of board positions and with an asset size of no more than 2 trillion won (2 billion USD). All estimations include both year and industry effects. Rnd2sale is lcapital is log of capital; sachine2N refers to expenditure on machines scaled by number of employees; lintangible is (natural) logaritim erformance is a latent variable extracted from the Principle Component Analysis using four performance-related variables: the firm's average operating income scaled by sales in the previous two years, Tobin's 0 , calculated by (market value of ordinary shares plus book value of debt) divided by book value of assets; inverse of volatility of share return, calculated by monthly-based standard deviation of share return; and continuously compounded share return. foreignshare is one-lagged equity ownership held by foreign investors; debt2equity is calculated by book value of debt scaled by equity; and findistress is unity when a firm had experienced consecutive net losses in the previous

$* * *, *$ and $*$ denote (two-tailed) significance at $1 \%, 5 \%$ and $10 \%$, respectively. P-values are in brackets. P-values are based on cluster-adjusted standard error. 11 is log likelihood. alpha refers to a constant parameter to make the Poisson variance incorrect. 


\footnotetext{
${ }^{1}$ Hermalin and Weisbach (2003) observe the existence of large boards although many researchers report that small size is more efficient. They argue examination of this counter-Darwinism is an interesting research topic.

${ }^{2}$ In Korea, two major financial restructuring processes were undertaken after the 1997 crisis. One was balance sheet restructuring, which included liquidating firms (and banks), purchasing non-performing loans and capital injections (to banks) by the government, and activating the market mechanism (i.e., mergers and acquisitions largely by foreign investors - so called 'fire sales'). The other major aspect was micro-level restructuring, such as reforming the corporate governance structure by amending laws, restructuring organisations, and understanding the importance of risk management and performance rather than a narrow expansion/growth orientation in national policy. Becht, Bolton and Roell (2005) argue for five further important factors: the worldwide wave of privatisations over the last two decades; pension fund reforms and the growth of private savings; the takeover wave of the 1980s; the deregulation and integration of the capital market; and a series of corporate scandals and corporate failures in the US in the early 2000s. For the cases of Anglo-American economies, refer to Morck, Wolfenzen and Yeung (2005), Hermalin and Weisbach (2003) and Booth and Deli (1996). Mack and Li’s (2001) research focuses on firms in Singapore where public enterprises are prevalent.

${ }^{3}$ For this reason, board size is related with board composition.

${ }^{4}$ Board regulation motivated firms to have smaller sized boards. The requirement of outside directors for at least 25 percent of board members has pressured listed firms to reduce the number of directors from (internal) senior executives. Given limited years of term for director position, however, it is also possible that board increase is done by appointing insiders not outside directors.

${ }^{5}$ This zero appointment figure could be overstated because the KLCA database treated missing values as zero appointment particularly during the early stage of the introduction of board regulations. We expect firms failed to comply with the regulations deliberately did not report. In contrast, firms complied with the regulations have an incentive to report. As such, the division between the actively and the passively should not be influenced seriously by this possible measurement error.

${ }^{6}$ However, we admit that firm age may also indicate the stage of firm maturity or even corporate culture rather than seniority.

7 The Korea Corporate Governance Service (KCGS) also provides information about outside directors. However, for our estimation we used the KLCA database because the KCGS information is based on surveys, which limits its coverage of firms, and it has greater possibility of measurement errors. Further, KCGS information is available only from 2002.

${ }^{8}$ In an unreported graph, we matched the distribution of board size compared with the Poisson distribution, which is based on the mean value of board size. This graph illustrates that the distribution of board size closely follows the Poisson distribution, justifying the use of the Poisson estimator.
} 
${ }^{9}$ Board members are subject to retirement, and the retirement system limits increases in board size. In particular, reforms following the 1997 crisis facilitated the move away from the traditional life-time employment system by introducing so-called 'honorary retirement plans' (Bae and Rowley 2001). We therefore included the square of Seniority to investigate this nonlinearity. The sign of the coefficients of this variable was negative as expected but was not statistically significant (not reported).

10 The Poisson estimator is an exponential family: $\frac{\partial E(y / \mathbf{x})}{\partial x_{k}}=\hat{\beta} \exp (\cdot) \times \frac{1}{x_{k}}$.

${ }^{11}$ We excluded large firms because these firms are required to appoint outside directors for at least 50 percent of the board members. 